Discussion Paper No. 06-075

German Inbound Investment, Corporate Tax Planning, and Thin-Capitalization Rules A Difference-in-Differences Approach

Michael Overesch and Georg Wamser

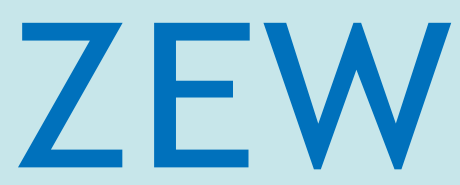

Zentrum für Europäische Wirtschaftsforschung $\mathrm{GmbH}$

Centre for European

Economic Research 


\section{Discussion Paper No. 06-075 \\ German Inbound Investment, Corporate Tax Planning, and Thin-Capitalization Rules - A Difference-in-Differences Approach}

Michael Overesch and Georg Wamser

Download this ZEW Discussion Paper from our ftp server:

ftp://ftp.zew.de/pub/zew-docs/dp/dp06075.pdf

Die Discussion Papers dienen einer möglichst schnellen Verbreitung von neueren Forschungsarbeiten des ZEW. Die Beiträge liegen in alleiniger Verantwortung der Autoren und stellen nicht notwendigerweise die Meinung des ZEW dar.

Discussion Papers are intended to make results of ZEW research promptly available to other economists in order to encourage discussion and suggestions for revisions. The authors are solely responsible for the contents which do not necessarily represent the opinion of the ZEW. 


\section{Non-Technical Summary}

Taxes play an important role in determining the capital structure of companies. Consequently, a multinational company would choose its capital structure according to differences in international taxation. Unlike purely national firms, multinationals can also use intercompany loans to shift profits between jurisdictions. Typically, high taxing countries try to restrict such inter-company loans by imposing so-called thin-capitalization or earning stripping rules in order to limit adverse revenue consequences. Although, these rules are theoretically suitable to get higher tax revenues, it is unclear whether governments can effectively limit inter-company debt shifting.

This paper investigates tax planning behavior by means of inter-company finance and the effectiveness of fighting back via thin-capitalization rules. By using a simple theoretical model, which considers the financing decision of a multinational and additionally takes into account a thin-capitalization rule, we show the tax response of the internal debt share: An affiliate's internal debt share increases with an increasing tax rate at the affiliate's location and with a decreasing tax rate at the parent company's location. Imposing a thin-capitalization rule at the affiliate's location limits interest deduction for tax purposes, and thus, the affiliate will use a smaller internal debt share.

The empirical analysis employs German inbound investment data provided by the Deutsche Bundesbank. We exploit legal amendments of the German thin-capitalization rule in 2001 and 2004 to obtain some exogenous variation in order to analyze its effect on the use of inter-company loans to German affiliates. A quasi-experimental setting enables us to use a difference-in-differences approach, since only some legal forms were treated by reforms in 2001 and 2004, respectively.

We find a significant impact of tax rate differences on the share of internal lending to German affiliates. This confirms earlier results provided by other studies. Furthermore, the empirical analysis shows that German thin-capitalization rules are effectively imposed. 
A reduction of the allowed debt-to-equity ratios, enforced by reforms in 2001 and 2004, induced significantly lower inter-company loan shares of incorporated companies. In other words, some companies, which were affected by a stricter thin-capitalization rule, subsequently adjusted their capital structure. Hence, tax planning via intra-firm finance was effectively limited by the German government. 


\title{
German Inbound Investment, Corporate Tax Planning, and Thin-Capitalization Rules - A Difference-in-Differences Approach
}

\author{
Michael Overesch \\ (ZEW) $\ddagger *$ \\ Georg Wamser \\ (ifo Institute) **
}

November 2006

\begin{abstract}
This paper investigates tax planning behavior by means of inter-company finance and the effectiveness of fighting back via thin-capitalization rules. A simple theoretical model, which considers the financing decision of a multinational company, is used to obtain empirical implications. The empirical analysis, based on German inbound investment data from 1996 until 2004, supports a significant impact of tax rate differences on the use of intra-company debt. The effectiveness of the German thin-capitalization rule is tested by using legal amendments as natural experiments. The results suggest that the German thin-capitalization rule induces significantly lower intra-firm debt-levels of inbound investments. Hence, tax planning via intra-firm finance is effectively limited.
\end{abstract}

Keywords: Corporate Income Tax, Multinationals, Thin-Capitalization Rule, Differencein-Differences, Firm-Level Data

JEL Classification: G32, H25, H26

\footnotetext{
${ }^{\ddagger}$ We are grateful to the Deutsche Bundesbank for granting access to the FDI database. Financial support by the German Research Foundation (DFG) is gratefully acknowledged.

${ }^{*}$ Centre for European Economic Research (ZEW), L 7,1, D-68163 Mannheim, Germany, overesch@zew.de.

**Ifo Institute for Economic Research, Poschingerstr. 5, D-81679 Munich, Germany, wamser@ifo.de.
} 


\section{Introduction}

It is a well established result, both theoretically and empirically, that taxes play an important role in determining the capital structure of companies (see e.g. Modigliani and Miller, 1958, 1963, as well as e.g. Desai, Foley and Hines, 2004). Consequently, a multinational company would choose its capital structure according to differences in international taxation. Unlike purely national firms, multinationals are not restricted to external lending; they can also lend to or borrow from affiliated companies and are therefore able to optimize their capital structure over all affiliates in order to minimize the tax burden of the whole company group. Especially, they can transform equity into inter-company loans in order to shift profits. Typically, high taxing countries try to restrict inter-company loans by imposing so-called thin-capitalization or earning stripping rules in order to limit adverse revenue consequences. Although these rules are theoretically suitable to get higher tax revenues (see Fuest and Hemmelgarn, 2005, Panteghini, 2006), it is unclear whether governments can effectively limit inter-company debt shifting.

In this paper we investigate whether intra-firm debt is tax driven. Furthermore, we test whether legal regulations can effectively restrict companies' tax planning behavior. For our empirical research we take German inbound investment data, which is, for several reasons, interesting for our analysis: First of all, Germany is a high tax country and hardly any other country has higher statutory corporate tax rates. Hence, using debt as a source of finance is sensible for German affiliates. Secondly, it is common practice that high tax countries try to restrict profit shifting, because they would lose high amounts of tax revenue. However, it is not clear whether Germany, or generally governments, are able to impose restrictions successfully. In this paper we exploit legal amendments of the German thin-capitalization rule - to obtain some exogenous variation - in order to analyze its effect on the use of inter-company loans given to German affiliates. A quasi-experimental setting enables us to use a difference-in-differences approach to identify whether the rule is effectively imposed, since only some legal forms were treated by reforms in 2001 and 2004, respectively. 
Empirical literature already provides some evidence for the tax rate sensitivity of companies with regard to their choice of capital structure. For Canadian and US-controlled firms Jog and Tang (2001) find a significant impact of differences in tax rates on financial choices; Huizinga, Laeven and Nicodème (2006) confirm this result for European firms. Ramb and Weichenrieder (2005) investigate the tax response of financial structures of German inbound FDI. Desai, Foley, and Hines (2004) show for US controlled affiliates that multinationals have a wide range of tax planning opportunities since they can also use internal borrowing. This result, in turn, is confirmed by Buettner, Overesch, Schreiber, Wamser (2006a) for German multinationals. So far, evidence on effects of thin-capitalization rules on companies' decisions has only been provided by Buettner, Overesch, Schreiber, Wamser (2006b). They find that thin-capitalization rules effectively restrict debt finance of German outbound investments. They also show that investment is more sensitive to taxes if debt finance is restricted. Our paper resumes this discussion by investigating the effectiveness of a thin-capitalization rule as a legal limitation of financial tax planning.

Our empirical analysis shows that bilateral tax rates are crucial for multinationals' capital structures. Using a difference-in-differences approach, our results suggest that the German thin-capitalization rule constitutes an effective limitation for profit-shifting activities. Particularly, our findings indicate that some companies, which were affected by a stricter thin-capitalization rule, subsequently adjusted their capital structure.

The paper is organized as follows: We start with some institutional details about the German thin-capitalization rule. Thereafter, we set up a theoretical model, which considers the financing decision of a multinational and additionally takes into account a thincapitalization rule. In section 4 we present the empirical investigation approach, in section 5 the data and some descriptive statistics. Section 6 answers the empirical question whether the German government successfully reduced tax-planning activities by imposing a stricter thin-capitalization rule. Finally, we conclude in part 7. 


\section{Some Institutional Details}

The high level of German company taxation, but also the comparatively low corporate tax revenues, are well documented (see European Communities, 2005). Firms are burdened with a very high statutory tax rate, which comprises a corporate income tax and, additionally, a local trade income tax. The high statutory tax rate rises incentives to shift profits out of Germany to other locations of multinational activity. A powerful method of shifting profits to low tax locations seems to be decisions on intra-firm financing.

First of all, it is reasonable to assume that a multinational company allocates inter-company loans optimally with respect to differences in international taxation. Hence, taxable profits are reduced by means of interest deduction. As a result, jurisdictions lose corporate tax revenue and consequently try to defend their tax base. A common tool to do this are thincapitalization rules, also called earning stripping rules. These rules such as section 8(a) of the German corporate income tax law (KStG) typically limit interest deduction up to a fixed relation between equity and inter-company debt, i.e. the interest paid for an excess leverage cannot be deducted from the tax base. Another way to restrict inter-company debt shifting is a general limitation of interest deduction for tax purposes. In Germany, for example, only half of interest payments can be deducted for purposes of the German local trade income tax.

Empirical identification of thin-capitalization rules, however, is difficult. In practice its appliance depends on several additional aspects among the pure debt-to-equity ratio. Some kind of intra-firm debt is excepted, such as debt which fulfills arm's length principle requirements, or trade accounts payable due to internal deliveries of input goods. Furthermore, the debt-to-equity ratio is not only limited to internal leverage. For instance, a strategy called back-to-back finance, in which external debt is borrowed by an affiliate and simultaneously secured by a deposit of the parent company, is also prohibited by the German thin-capitalization rule. Whether back-to-back finance is eventually considered as parent- 
company debt-finance is often a matter of negotiation with tax authorities. Hence, we are not able to identify single companies in the data which are affected by thin-capitalization rules, although we know the exact German threshold levels. Therefore, we use changes in the German thin-capitalization rule for some companies, depending on their legal form, to obtain exogenous variation in one crucial explanatory variable.

The German thin-capitalization rule only applies to foreign affiliates which are incorporated. ${ }^{1}$ First-tier foreign partnerships are not treated by the German thin-capitalization rule and constitute a suitable non-treatment group while looking at legal amendments of this rule as natural experiments. The rule classifies two different types of incorporated companies. The first group of companies comprises ordinary corporations, which are not classified as holdings. For purposes of this law, a holding is defined as a firm where more than $75 \%$ of total assets consist of shares in other corporations. For ordinary corporations, the allowed debt-to-equity ratio, called safe haven, was accepted at 3:1 before 2001. Yet, the safe haven debt-to-equity ratio was 9:1 in case of a holding corporation, i.e. holdings could be used as loopholes. In 2001 and 2004, two important amendments of the German thin-capitalization rule were enforced. In 2001 the allowed debt-to-equity ratios were significantly reduced to $1.5: 1$ in the case of an ordinary corporation and to $3: 1$ in the case of a holding corporation, respectively. Nevertheless, a possible loophole in the shape of holding corporations remained. In 2004, this special rule for holding corporations was also abolished, i.e. the safe haven was generally constituted at 1.5:1 for every corporation. However, first-tier partnerships were not affected by these amendments.

To illustrate the change of the German thin-capitalization rule, let us consider the following example. A German holding corporation uses internal debt as a source of finance. The German tax authority classified its debt-to-equity relation at 4:1 in 2000. Then, this corporation was allowed to deduct interest payments without restriction. Following the

\footnotetext{
${ }^{1}$ An exemption is that since 2004 the German thin-capitalization rule applies to cases where a secondtier partnership is held by incorporated foreign affiliates. However, these cases are not considered by our analysis.
} 
2001 tax reform, however, the maximum allowed relation was reduced to $3: 1$. Therefore the corporation was no longer allowed to deduct interest payments for 5 percentage points of its debt-to-equity share. Nevertheless, the corporation is not prohibited to maintain its debt-to-equity ratio. Maintaining the old ratio is yet getting less valuable for the firm since a tax shield is not generated anymore. Note, however, that not every corporation - irrespective of its legal form - is affected by a stricter thin-capitalization rule. Possibly some firms are below the required debt-to-equity relation anyway. We come back to that point in section 6 , discussing what this implies for the estimated coefficients.

\section{A Model}

The impact of company taxation on the choice of debt or equity as a subsidiary's source of finance can be explained by the following simple model. We consider a firm with two separate companies, where the parent company is denoted by 1 and the subsidiary by 2 . If the subsidiary is completely financed by intra-firm equity, profits are determined by

$$
\pi=f\left(k_{1}\right)\left(1-t_{1}\right)+f\left(k_{2}\right)\left(1-t_{2}\right)-r\left(k_{1}+k_{2}\right) .
$$

Where $k_{1}$ and $k_{2}$ denote invested capital, and $t_{1}$ and $t_{2}$ the statutory tax rates at the respective locations. The opportunity costs of own capital are $r\left(k_{1}+k_{2}\right)$. Note that an exemption system of repatriated foreign profits is assumed. ${ }^{2}$

The parent company can decide on the capital type, which is used to finance the subsidiary. Instead of equity, the parent company can give capital as an intra-firm credit. We denote the share of capital, which is financed by such an internal credit as $\mu_{2}$, and the intra-firm

\footnotetext{
${ }^{2}$ This is true for most of European countries and Canada. Furthermore, the effect of a credit system equals an exemption system if $t_{2}>t_{1}$, which is true for our analysis in several cases, considering the high German tax rate. Otherwise, the affiliate's tax rate increases to $t_{1}$, depending on the time of retention. However, the general incentives remain if foreign profits are not distributed immediately.
} 
interest rate as $i_{2}$. Intra-firm interest payments, $i_{2} \mu_{2}$, can be deducted for tax purposes by the borrowing subsidiary 2 . Simultaneously, interest payments are taxed at the lending company. Hence, the tax consequence of an intra-firm credit amounts to

$$
i_{2} \mu_{2} k_{2}\left(t_{2}^{i}-t_{1}\right)
$$

where $t_{2}^{i}$ is the tax rate avoided because of interest deduction. This tax rate can be different from the statutory company tax rate if interest payments are not fully deductible from corporate income. For example, this is true in the case of Germany, where only half of interest payments can be deducted for local income tax purposes, i.e. $t_{2}^{i}<t_{2}$.

Moreover, it is reasonable to consider some costs which are connected with the use of intra-firm loans and depend on the level of intra-firm debt (see Jensen and Meckling, 1976, Myers, 1977). These costs might arise from tax as well as non-tax constraints, such as costs arising from asymmetric information and agency costs, or a higher risk that interest deduction will not be permitted for tax purposes anymore. Therefore, we assume a cost function $c_{2}\left(\mu_{2}\right)$, which has the following properties

$$
\frac{d c_{2}}{d \mu_{2}}>0, \quad \frac{d^{2} c_{2}}{d \mu_{2}^{2}}>0
$$

Nevertheless, there are also non-tax reasons to use inter-company debt such as shortterm cash management between parent and affiliate, or the opportunity to control the local management by fixed annual interest payments (see Jensen, 1986). Therefore, it is reasonable to assume a utility function $g_{2}\left(\mu_{2}\right)$, which has the following properties

$$
\frac{d g_{2}}{d \mu_{2}}>0, \quad \frac{d^{2} g_{2}}{d \mu_{2}^{2}}<0 .
$$


Then, the profit function of the firm can be described as

$$
\begin{aligned}
\pi & =f\left(k_{1}\right)\left(1-t_{1}\right)+f\left(k_{2}\right)\left(1-t_{2}\right)-r\left(k_{1}+k_{2}\right) \\
& +\left[i_{2} \mu_{2}\left(t_{2}^{i}-t_{1}\right)-c_{2}\left(\mu_{2}\right)+g_{2}\left(\mu_{2}\right)\right] k_{2} .
\end{aligned}
$$

Obviously, the transition of equity into intra-firm debt implies a direct profit-shift from the borrowing affiliate 2 into the lending parent company 1, which is favorable in cases the tax rate of the borrowing affiliate is higher than the tax rate of the lender.

The tax rate difference between both locations indicates an incentive to use equity refinanced internal debt as a tool to shift profits from the borrowing affiliate into the lending one. However, jurisdictions defend against these kind of tax base alleviation via intracompany debt by limiting interest deductions. These thin-capitalization rules typically limit interest deduction, i.e. the interest paid for an excess leverage cannot be deducted from the tax base if $\mu_{j}$ is above some fixed $\overline{\mu_{j}}$. Hence, the profit function must be extended by the additional tax payments arising from excess leverage above the limits claimed by the thin-capitalization rule. Assuming that country 2 introduces such a rule, this can be described by $\varphi_{2}$, where $\varphi_{2}=1$ if the rule is effectively binding, and 0 otherwise. Whether the rule is binding for an affiliate depends on the difference between the inter-company debt share and the maximally allowed ratio, i.e. whether a company is above the threshold level or not, and how the type of internal debt is classified for tax purposes. Note that $\varphi_{2}$ is always 0 if $\mu_{2}<\overline{\mu_{2}}$. Then, the profit consequence of a thin-capitalization rule can be written as

$$
-i_{2}\left(\mu_{2}-\overline{\mu_{2}}\right) t_{2}^{i} \varphi_{2} k_{2}
$$

Hence, the profit function (1) becomes

$$
\begin{aligned}
\pi & =f\left(k_{1}\right)\left(1-t_{1}\right)+f\left(k_{2}\right)\left(1-t_{2}\right)-r\left(k_{1}+k_{2}\right) \\
& +\left[i_{2} \mu_{2}\left(t_{2}^{i}-t_{1}\right)-i_{2}\left(\mu_{2}-\overline{\mu_{2}}\right) t_{2}^{i} \varphi_{2}-c_{2}\left(\mu_{2}\right)+g_{2}\left(\mu_{2}\right)\right] k_{2} .
\end{aligned}
$$


The optimum share of intra-firm debt of the subsidiary 2 financed by equity of the parent company is obtained by the following first-order condition

$$
i_{2}\left(t_{2}^{i}-t_{1}-t_{2}^{i} \varphi_{2}\right)+g_{2, \mu}\left(\mu_{2}\right)-c_{2, \mu}\left(\mu_{2}\right) \stackrel{!}{=} 0
$$

First, we consider the case without application of any thin-capitalization rule. Accordingly, the share of intra-firm debt is determined by the tax rate difference between the borrowing affiliate and the parent company, $\left(t_{2}^{i}-t_{1}\right)$. The intra-firm lending rate can be used to leverage the tax effect. However, the intra-firm interest rate is probably not an important degree of freedom, since the arm's length principle can easily be applied.

Secondly, we consider cases where the thin-capitalization rule is applied. If $\varphi_{2}$ becomes 1, any tax incentive to use intra-company debt refinanced by equity due to the level of the borrowing affiliate's tax rate is effectively stopped. Then, only the level of the tax rate at the lending parent company has an impact. Additionally, intra-firm debt used for non-tax reasons becomes more expensive, since intra-firm interest payments are effectively taxed two times, at the affiliate level and at the parent company. Then, it should often be cheaper to reduce $\mu_{2}$ - assuming a binding case - in order to avoid enforcement of the thin-capitalization rule.

We can derive comparative static properties by differentiating the first-order condition,

$$
-i_{2} d t_{1}+\left[i_{2}-i_{2} \varphi_{2}\right] d t_{2}^{i}+\left[t_{2}^{i}-t_{1}-t_{2}^{i} \varphi_{2}\right] d i_{2}=\left[c_{2, \mu \mu}\left(\mu_{2}\right)-g_{2, \mu \mu}\left(\mu_{2}\right)\right] d \mu_{2} .
$$

First, let us consider the effect of an increasing tax rate at the lending company's location on the share of intra-firm debt used by its affiliate. ${ }^{3}$ The derivative equals

$$
\frac{d \mu_{2}}{d t_{1}}=\frac{-i_{2}}{c_{2, \mu \mu}\left(\mu_{2}\right)-g_{2, \mu \mu}\left(\mu_{2}\right)}<0 \text {. }
$$

\footnotetext{
${ }^{3}$ We assume that the marginal effects of tax rate variations on the intra-firm interest rate $i_{2}$ equal zero. This is a reasonable assumption, since the arm's length principle can easily be applied on interest rates.
} 
Expression (4) is always negative, i.e. the intra-firm debt used by an affiliate decreases with an increasing tax rate at the parent's location. With regard to the marginal effect of an increasing tax rate at the affiliate's location, we obtain

$$
\frac{d \mu_{2}}{d t_{2}^{i}}=\frac{i_{2}-i_{2} \varphi_{2}}{c_{2, \mu \mu}\left(\mu_{2}\right)-g_{2, \mu \mu}\left(\mu_{2}\right)} \geq 0
$$

This expression is positive when the thin-capitalization rule is not enforced, i.e. $\varphi_{2}=0$. Otherwise, if the share of intra-firm debt is above the limits, i.e. $\varphi_{2}=1$, an increasing tax rate has no effect on the optimal share of intra-firm debt. This can be explained by the fact that interest payments for the excessive intra-firm debt above the limit cannot be deducted for tax purposes. Higher levels of intra-firm debt must be due to non-tax reasons, e.g. short-term cash management. Accordingly, a changing tax rate does not matter for the optimal intra-firm debt in these cases. To sum up, the following proposition can be set up:

Proposition 1: The optimal share of intra-firm debt should increase with an increasing tax rate at the subsidiary's location and decrease with an increasing tax rate at the parent's location. Hence, if the share of intra-firm debt is tax driven, the share of intra-firm debt should increase with an increasing tax rate difference, $\left(t_{2}^{i}-t_{1}\right)$, between subsidiary and parent location.

Finally, let us consider changes of the allowed share of intra-firm debt by legal amendments of the thin-capitalization rule. The German reforms of the thin-capitalization rule significantly reduced the safe haven in 2001 and 2004, respectively. It is obvious that a reduction of $\overline{\mu_{2}}$ increases the number of cases, where $\varphi_{2}$ becomes one, i.e. where the rule is binding and enforced. In other words, given any distribution of $\mu$, a stricter thin-capitalization rule effects that more companies are above the now lower threshold level. However, it should be emphasized that identification of each affected company is not possible due to various reasons we already discussed in section 2. Equation (3) implies that, as a consequence, the tax incentive to use intra-firm debt decreases. Then, the firm will reduce its debt 
share below the new threshold level, and prefers equity as the marginal source of finance. Therefore, we would expect that the level of intra-firm debt has decreased on average since 2001 and 2004, respectively.

Proposition 2: If intra-firm debt is a channel to shift taxable profits, and the German thincapitalization rule is likely to limit this tax planning behavior, a reduction of the allowed debt-to-equity ratio should lead to smaller shares of intra-firm debt. Non-incorporated companies, which are not treated by the German thin-capitalization rule and its amendments, should not exhibit a reduction of intra-firm debt.

\section{Empirical Implications}

The propositions set up above can be tested empirically by using data on German inbound FDI. A simple estimation approach to test proposition 1 could be a regression of the intercompany leverage, denoted by ICL, of an investment in country $G$ (Germany) taken by firm $k$ located in country $j$ in period $t$ on the tax rate difference $S T R_{G, t}-S T R_{j, t}$ and on some company specific characteristics $x_{j, t}$. Then, a simple regression equation would be

$$
I C L_{k, j, t}=a_{0}+a_{1}\left(S T R_{G, t}-S T R_{j, t}\right)+a_{2} x_{k, j, t}+a_{k}+a_{t}+\epsilon_{k, j, t}^{I C L},
$$

where $a_{k}$ is a company-specific effect to control for firm heterogeneity. Furthermore, we control for German capital market constraints or aggregate shocks by a time-specific effect $a_{t}$. Note that identification of the tax rate effect results from variation in $S T R_{j, t}$. Yearly changes in $S T R_{G, t}$ can also be seen as aggregate shocks, because we analyze inbound investments in only one country, Germany. Following proposition 1, we expect a positive sign of the tax difference coefficient $a_{1}$ on the share of intra-firm debt $I C L$. In case of internal debt, which is refinanced by equity, the local interest rate at the lending parent country should be irrelevant. Only the lending rate at the borrowing subsidiary location, 
Germany, might be important, since it is used as the arm's length benchmark by the German tax authority. However, we implicitly control for the German lending rate by time effects $a_{t}$, since every inbound investor faces the same lending rate.

The expected limitation of tax planning via intra-firm debt by the German thin- capitalization rule, as claimed in proposition 2, can also be tested empirically using German inbound FDI data. As described above in section 2, two important amendments of the German thin-capitalization rule came into force in 2001 and 2004, respectively. It should be noted again that we cannot look directly at those companies having a debt-to-equity ratio, which is most probably affected by the thin-capitalization rule. However, the reforms constitute a exogenous sources of variation, unambiguously affecting our dependent variable on average. Then, the effects of these amendments on the use of internal debt can be tested by a difference-in-differences approach (see for example Meyer, 1995).

Since the different amendments of the German thin-capitalization rule have constituted three groups with different degrees of treatment, we use a dummy variable $D_{T G R O U P}$, indicating the respective treatment group, i.e. the corporations, which were treated by a specific amendment of the thin-capitalization rule in 2001 or 2004, respectively. Additionally, we use a dummy variable $D_{\text {post }}$ to indicate the post amendment observations from 2001 to 2004. Then, an estimation equation for the 2001 reform effect can be described as

$$
I C L_{k, j, t}=b_{0}+b_{1}\left(S T R_{G, t}-S T R_{j, t}\right)+b_{2} x_{k, j, t}+b_{3} D_{T G R O U P}+b_{4} D_{T G R O U P} D_{p o s t}+b_{k}+b_{t}+\epsilon_{k, j, t}^{I C L} .
$$

The treatment group consists of both ordinary corporations and holding corporations. Remember, however, partnerships were not treated by the German thin-capitalization rule and constitute a suitable non-treatment group of the reform in 2001. Group-independent time trends are absorbed by $b_{t}$. Therefore, we implicitly control for yearly variations in German tax rates, since German conditions are the same for every single inbound investment. The treatment effect is measured by $b_{4}$, for which we expect a negative sign. However, it is reasonable to distinguish within the treated group, since the reduction of the 
safe haven of holding corporations was significantly higher compared to the reduction for ordinary corporations. Therefore, we also carry out different regressions based on equation (7), considering each of these treatment groups.

For the 2004 reform effect, we propose the following equation

$$
I C L_{k, j, t}=c_{0}+c_{1}\left(S T R_{G, t}-S T R_{j, t}\right)+c_{2} x_{k, j, t}+c_{3} D_{T G R O U P}+c_{4} D_{T G R O U P} D_{2004}+c_{k}+c_{t}+\epsilon_{k, j, t}^{I C L}
$$

where only holdings were treated by the reform of the German thin-capitalization rule in 2004. Therefore, all other companies, incorporated and non-incorporated, constitute the non-treatment group. We would also expect a negative sign of the treatment effect $c_{4}$.

To sum up, the legal reforms enable us to test whether a thin-capitalization rule is imposed effectively. The tax reform of 2001 hit only ordinary incorporated as well as holding companies. Partnerships, however, were not affected. In 2004, only holding corporations were affected. We argue that these different groups are comparable. This is a reasonable assumption since we observe only affiliates of multinationals. Hence, we look at firms which have the same opportunities with respect to e.g. inter-company loan finance. Furthermore, we control for differences across single investments, e.g. by using the affiliate specific turnover. We additionally assume that there are no systematic changes in within- and between-group compositions. In fact, our group sizes are almost stable over time. To identify the effect on the treated companies, a further critical assumption is that both groups are equally affected by aggregate shocks.

\section{$5 \quad$ Data and Descriptive Statistics}

The empirical analysis uses the MiDi database for multinationals provided by the Deutsche Bundesbank. This is a comprehensive annual micro database of direct investment positions of German enterprises held abroad as well as of direct investment positions held in Ger- 
Table 1: German Inbound FDI 1996 - 2004

\begin{tabular}{|c|c|c|c|c|}
\hline $\begin{array}{l}\text { Home } \\
\text { Country }\end{array}$ & $\begin{array}{r}\text { Number of } \\
\text { Observations }\end{array}$ & $\begin{array}{l}\text { Share of Internal } \\
\text { Debt from Foreign } \\
\text { Parent Company }\end{array}$ & $\begin{array}{l}\text { Tax Rate } \\
\text { Difference }\end{array}$ & $\begin{array}{c}\text { Average } \\
\text { Number of } \\
\text { Investments (yearly) }\end{array}$ \\
\hline Australia & 33 & .358 & .021 & 4 \\
\hline Austria & 1,245 & .240 & .019 & 139 \\
\hline Belgium & 564 & .284 & -.033 & 64 \\
\hline Canada & 162 & .280 & -.063 & 19 \\
\hline Cyprus & 21 & .215 & .130 & 3 \\
\hline Czech Rep & 40 & .340 & .019 & 5 \\
\hline Denmark & 745 & .284 & .040 & 83 \\
\hline Finland & 189 & .345 & .077 & 22 \\
\hline France & 1,988 & .249 & -.014 & 223 \\
\hline Great Britain & 1,276 & .270 & .051 & 144 \\
\hline Greece $^{a)}$ & & . & 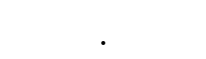 & . \\
\hline Hungary & 39 & .367 & .158 & 5 \\
\hline Iceland ${ }^{a)}$ & 12 & .283 & .074 & . \\
\hline Ireland & 63 & .488 & .251 & 8 \\
\hline Italy & 905 & .281 & -.069 & 101 \\
\hline Japan & 2,257 & .339 & -.100 & 252 \\
\hline Korea (Rep.) & 165 & .393 & .056 & 21 \\
\hline Lithuania $^{a)}$ & & . & . & . \\
\hline Luxembourg & 388 & .235 & .001 & 44 \\
\hline Mexico $^{a}$ ) & 12 & .138 & .014 & . \\
\hline Netherland & 2,429 & .281 & .010 & 273 \\
\hline Norway & 177 & .279 & .078 & 21 \\
\hline Poland & 30 & .212 & .042 & 3 \\
\hline Portugal & 25 & .281 & .038 & 3 \\
\hline Slovakia ${ }^{a}$ & & . & . & . \\
\hline Slovenia & 75 & .221 & .109 & 9 \\
\hline Spain & 300 & .211 & -.043 & 35 \\
\hline Sweden & 565 & .249 & .076 & 64 \\
\hline Switzerland & 2,725 & .276 & .112 & 306 \\
\hline Turkey & 51 & .316 & -.013 & 6 \\
\hline USA & 2,880 & .280 & -.051 & 330 \\
\hline Total & 19,379 & .280 & .003 & 2,195 \\
\hline
\end{tabular}

a) Not reported because of data protection.

many by foreign companies. However, we use only the German inbound FDI data. The 
data provides information about the investment object's balance sheet, including further information on the type of investment and on the investor. A favorable characteristic of the data set is the possibility to trace direct investment positions of individual firms over time. The current version provides firm-level panel data for the period 1996 to 2004. The collection of the data is enforced by German law, which requires reporting obligations for certain international transactions and positions. ${ }^{4}$ With regard to inbound FDI, each German enterprise has to report if it is held by a foreign investor. The database comprises direct FDI and indirect FDI positions, though, only if holdings are above some threshold level. As the model deals with a simple two-tier company structure, indirectly held investments are excluded. Moreover, we keep only observations which exhibit a non-zero intra-firm debt share.

Table 2: Descriptive Statistics

\begin{tabular}{llrrrr}
\hline \hline Variable & Definition & Mean & Std.Dev. & Min. & Max. \\
& & & & & \\
\hline ICL & $\begin{array}{l}\text { internal debt share from } \\
\text { foreign parent company }\end{array}$ & .280 & .262 & .001 & .999 \\
& & & & \\
$S T R_{G}-S T R_{F}$ & tax rate difference & .003 & .072 & -.152 & .281 \\
$S T R_{F}$ & foreign tax rate & .354 & .071 & .100 & .532 \\
Loss carry-forward & binary & .431 & .495 & 0 & 1 \\
Turnover & turnover in $€ 1,000$ & 65,088 & 247,678 & 1,000 & $13,500,000$ \\
\hline
\end{tabular}

Observations: 19,379 .

According to equation (6), we calculate the inter-company loan, borrowed from the foreign parent company, to total capital ratios, ICL, using the Midi data. In order to control for company-specific variation in the accession to external debt, we employ the turnover as an indicator of the size and the affiliate's cash-flow. We expect a negative effect of a higher

\footnotetext{
${ }^{4}$ Sec. 26 Aussenwirtschaftsgesetz (Law on Foreign Trade and Payments) in connection with Aussenwirtschaftsverordnung (Foreign Trade and Payment Regulations). Since 2002, FDI has to be reported, if the participation is $10 \%$ or more and the balance sheet total of the foreign investment in Germany is above 3 million Euro. For details see Lipponer (2006). Though previous years showed lower threshold levels, we apply this threshold level uniformly for all years in the panel.
} 
turnover when external and internal debt serve as substitutes (see Buettner et al., 2006a). As agency costs and utility of intra-firm debt may also vary across industries, we control for further heterogeneity by including dummies for 56 industries at the level of the affiliate.

The statutory tax rate difference constitutes the relevant measure to investigate the tax impact on the use of intra-firm debt. The variable $S T R_{G}$ contains German statutory profit tax rates ${ }^{5}$ foreign statutory tax rates are denoted by $S T R_{F}$. While using these two tax measures, bilateral tax rate differences are constructed. Since the effective tax reduction from using debt might be zero if a subsidiary carries forward any losses for tax purposes (see MacKie-Mason, 1990), we include a dummy variable indicating whether some loss carry-forward is reported. Of course, the existence of some losses in the previous periods may capture other characteristics of the current decision problem of the company such as the expected performance of an affiliate. Thus, the overall effect on internal leverage is ambiguous.

Table 1 displays the number of observations in our sample, means of the share of non German internal debt, means of the country specific tax rate differences, and the yearly average number of investment objects. Investors are mainly from Germany's European neighbor countries, e.g. Switzerland, Austria, France, or the Netherlands. Of course, investors from big other economies like Japan or the USA are also strongly represented. Table 2 displays basic information about the variables used in regressions later on.

\section{Empirical Results}

The empirical analysis involves panel-data regressions, which include firm level fixed effects. Hence, by using a within estimator, we generally control for all company specific

\footnotetext{
${ }^{5}$ The German statutory tax rate we use considers that only half of interest payments can be deducted from the tax base of the German trade income tax. Furthermore, a country-average level of the local trade income tax is considered.
} 
heterogeneity at the level of the company.

First of all, it is worth to mention that all regressions show the expected tax rate effect. In table 3, specification (2) indicates, for example, that a 10 percentage point increase in the tax rate difference between Germany and any other country is associated with a 1.9 percentage point higher internal-debt ratio. The magnitude of the tax effect is in line with earlier findings, see e.g. Desai, Foley, and Hines (2004) or Buettner et al. (2006a). This result indicates that taxes, in this case tax differences between Germany and foreign countries, play an important role for choices of financial structures, and companies react according to these differences in taxation.

With regard to the effect of the German thin-capitalization reform in 2001, we control for a systematic difference in control and treatment group by introducing a group dummy variable, $D_{\text {TGROUP. }}$. First, we do not differ between different treatment groups in specifications (3)-(5) of table 3. While we interact the treatment group with a post reform dummy, $D_{P O S T}$, for the whole period 2001 until 2004 in column (3), we control for each year in columns (4) and (5). In column (4) we see that the treated group, i.e. holdings and incorporated firms, responds to the tighter thin-capitalization rule, and internal lending is reduced in the after reform period. Column (5) shows that the reform was by no means anticipated. Rather, it took the companies one year to reduce their internal debt shares. Possibly, the findings of 2002 are the result of a restructuring process which started in 2001, right after the unanticipated reform.

Remember that a company is only affected if the thin-capitalization rule is binding, i.e. if the firm's debt-to-equity share is above the maximally allowed share. Then, the firm should re-optimize because of the aggravation of the imposed rule if the financial construction so far was optimal due to tax planning behavior. Nevertheless, given the continuum of internal-debt-to-equity shares, not all corporations are affected. Then, the mean share is going down for the whole treatment group, because of some corporation. As a consequence, the treatment effect would be much higher if all treated corporations were really affected. 
Table 3: Inter Company Loans - Thin-Capitalization Reform in 2001

\begin{tabular}{|c|c|c|c|c|c|}
\hline & (1) & $(2)$ & $(3)$ & (4) & $(5)$ \\
\hline$S T R_{G}-S T R_{F}$ & $\begin{array}{l}.188{ }^{\star} \\
(.088)\end{array}$ & $\begin{array}{l}.1922^{\star} \\
(.088)\end{array}$ & $\begin{array}{l}.206{ }^{\star} \\
(.087)\end{array}$ & $\begin{array}{l}.207^{\star \star} \\
(.087)\end{array}$ & $\begin{array}{l}.214^{\star \star} \\
(.088)\end{array}$ \\
\hline$D_{T G R O U P}$ & & & $\begin{array}{l}.001 \\
(.019)\end{array}$ & $\begin{array}{l}.002 \\
(.019)\end{array}$ & $\begin{array}{l}.018 \\
(.020)\end{array}$ \\
\hline$D_{T G R O U P} x D_{P O S T}$ & & & $\begin{array}{l}-.025 \star \\
(.010)\end{array}$ & & \\
\hline$D_{\text {TGROUP }} x 1997$ & & & & & $\begin{array}{l}-.006 \\
(.018)\end{array}$ \\
\hline$D_{\text {TGROUP }} x 1998$ & & & & & $\begin{array}{l}-.016 \\
(.019)\end{array}$ \\
\hline$D_{\text {TGROUP }} x 1999$ & & & & & $\begin{array}{l}-.025 \\
(.017)\end{array}$ \\
\hline$D_{T G R O U P} x 2000$ & & & & & $\begin{array}{l}-.024 \\
(.018)\end{array}$ \\
\hline$D_{\text {TGROUP }} x 2001$ & & & & $\begin{array}{l}-.004 \\
(.012)\end{array}$ & $\begin{array}{l}-.021 \\
(.020)\end{array}$ \\
\hline$D_{\text {TGROUP }} x 2002$ & & & & $\begin{array}{l}-.036 \text { * } \\
(.015)\end{array}$ & $\begin{array}{l}-.052 \text { * } \\
(.023)\end{array}$ \\
\hline$D_{\text {TGROUP }} x 2003$ & & & & $\begin{array}{l}-.032 \text { * } \\
(.011)\end{array}$ & $\begin{array}{l}-.049{ }^{\star} \\
(.020)\end{array}$ \\
\hline$D_{\text {TGROUP }} x 2004$ & & & & $\begin{array}{l}-.038 \star \\
(.016)\end{array}$ & $\begin{array}{l}-.054{ }^{\star} \\
(.023)\end{array}$ \\
\hline 1997 & $\begin{array}{l}-.003 \\
(.005)\end{array}$ & $\begin{array}{l}-.003 \\
(.005)\end{array}$ & $\begin{array}{l}-.003 \\
(.005)\end{array}$ & $\begin{array}{l}-.003 \\
(.005)\end{array}$ & $\begin{array}{l}.003 \\
(.017)\end{array}$ \\
\hline 1998 & $\begin{array}{l}-.002 \\
(.006)\end{array}$ & $\begin{array}{l}-.002 \\
(.006)\end{array}$ & $\begin{array}{l}-.002 \\
(.006)\end{array}$ & $\begin{array}{l}-.002 \\
(.006)\end{array}$ & $\begin{array}{c}.013 \\
(.017)\end{array}$ \\
\hline 1999 & $\begin{array}{l}-.001 \\
(.005)\end{array}$ & $\begin{array}{l}-.001 \\
(.005)\end{array}$ & $\begin{array}{l}-.002 \\
(.005)\end{array}$ & $\begin{array}{l}-.002 \\
(.005)\end{array}$ & $\begin{array}{c}.022 \\
(.016)\end{array}$ \\
\hline 2000 & $\begin{array}{l}-.000 \\
(.006)\end{array}$ & $\begin{array}{l}-.000 \\
(.006)\end{array}$ & $\begin{array}{l}-.000 \\
(.006)\end{array}$ & $\begin{array}{l}-.000 \\
(.006)\end{array}$ & $\begin{array}{c}.022 \\
(.017)\end{array}$ \\
\hline 2001 & $\begin{array}{c}.002 \\
(.005)\end{array}$ & $\begin{array}{c}.002 \\
(.005)\end{array}$ & $\begin{array}{l}.025^{\star \star} \\
(.011)\end{array}$ & $\begin{array}{c}.006 \\
(.012)\end{array}$ & $\begin{array}{c}.022 \\
(.019)\end{array}$ \\
\hline 2002 & $\begin{array}{l}-.011 \\
(.006)\end{array}$ & $\begin{array}{l}-.010 \\
(.007)\end{array}$ & $\begin{array}{l}.013 \\
(.011)\end{array}$ & $\begin{array}{c}.023 \\
(.015)\end{array}$ & $\begin{array}{c}.038 \\
(.021)\end{array}$ \\
\hline 2003 & $\begin{array}{l}-.024^{\star \star} \\
(.006)\end{array}$ & $\begin{array}{l}-.024^{\star \star} \\
(.006)\end{array}$ & $\begin{array}{l}-.001 \\
(.010)\end{array}$ & $\begin{array}{c}.006 \\
(.011)\end{array}$ & $\begin{array}{c}.020 \\
(.018)\end{array}$ \\
\hline 2004 & $\begin{array}{l}-.0222^{\star \star} \\
(.007)\end{array}$ & $\begin{array}{l}-.0222^{\star \star} \\
(.007)\end{array}$ & $\begin{array}{c}.001 \\
(.007)\end{array}$ & $\begin{array}{c}.013 \\
(.016)\end{array}$ & $\begin{array}{c}.028 \\
(.021)\end{array}$ \\
\hline $\ln$ (Turnover) & $\begin{array}{l}-.0166^{\star \star} \\
(.004)\end{array}$ & $\begin{array}{l}-.015^{\star \star} \\
(.004)\end{array}$ & $\begin{array}{l}-.015^{\star \star} \\
(.004)\end{array}$ & $\begin{array}{l}-.015^{\star \star} \\
(.004)\end{array}$ & $\begin{array}{l}-.015^{\star \star} \\
(.004)\end{array}$ \\
\hline Loss carry-forward & & $\begin{array}{c}.009 \\
(.005) \\
\end{array}$ & $\begin{array}{c}.009 \\
(.005) \\
\end{array}$ & $\begin{array}{c}.009 \\
(.005) \\
\end{array}$ & $\begin{array}{c}.009 \\
(.005) \\
\end{array}$ \\
\hline $\begin{array}{l}\text { Observations } \\
R^{2}\end{array}$ & $\begin{array}{c}19,379 \\
.026\end{array}$ & $\begin{array}{c}19,379 \\
.026\end{array}$ & $\begin{array}{c}19,379 \\
.027\end{array}$ & $\begin{array}{c}19,379 \\
.027\end{array}$ & $\begin{array}{c}19,379 \\
.027\end{array}$ \\
\hline
\end{tabular}

Dependent variable is the share of inter-company loans borrowed from the foreign parent company. Robust and clustered (country/year clusters) standard errors are in parentheses. A star denotes significance at $5 \%$ and two stars at the $1 \%$ level. All estimates include a full set of 5,257 firm, 56 industry, and year fixed effects. 
Table 4: Inter Company Loans - Thin-Capitalization Reform in 2001

\begin{tabular}{|c|c|c|c|c|c|c|}
\hline & $(1)$ & $(2)$ & $(3)$ & $(4)$ & $(5)$ & $(6)$ \\
\hline$S T R_{G}-S T R_{F}$ & $\begin{array}{l}.201{ }^{\star} \\
(.089\end{array}$ & $\begin{array}{l}.216^{\star} \\
(.088)\end{array}$ & $\begin{array}{l}.224{ }^{\star} \\
(.090)\end{array}$ & $\begin{array}{l}.783^{\star \star} \\
(.287)\end{array}$ & $\begin{array}{l}.7500^{\star \star} \\
(.288)^{\circ}\end{array}$ & $\begin{array}{l}.737^{\star \star} \\
(.294)\end{array}$ \\
\hline$D_{T G R O U P}$ & & $\begin{array}{l}.003 \\
(.019)\end{array}$ & $\begin{array}{l}.019 \\
(.020)\end{array}$ & & $\begin{array}{l}.019 \\
(.074)\end{array}$ & $\begin{array}{l}.100 \\
(.084)\end{array}$ \\
\hline$D_{\text {TGROUP }} x D_{P O S T}$ & & $\begin{array}{l}-.025^{\star} \\
(.010)\end{array}$ & & & $\begin{array}{l}-.101 \star \star \star \\
(.018)\end{array}$ & \\
\hline$D_{\text {TGROUP }} x 1997$ & & & $\begin{array}{l}-.006 \\
(.018)\end{array}$ & & & $\begin{array}{l}-.044 \\
(.028)\end{array}$ \\
\hline$D_{\text {TGROUP }} x 1998$ & & & $\begin{array}{l}-.017 \\
(.019)\end{array}$ & & & $\begin{array}{l}-.017 \\
(.035)\end{array}$ \\
\hline$D_{\text {TGROUP }} x 1999$ & & & $\begin{array}{l}-.026 \\
(.017)\end{array}$ & & & $\begin{array}{l}-.036 \\
(.032)\end{array}$ \\
\hline$D_{\text {TGROUP }} x 2000$ & & & $\begin{array}{l}-.024 \\
(.018)\end{array}$ & & & $\begin{array}{l}-.0855^{\star} \\
(.034)\end{array}$ \\
\hline$D_{\text {TGROUP }} x 2001$ & & & $\begin{array}{l}-.020 \\
(.020)\end{array}$ & & & $\begin{array}{l}-.125^{\star} \\
(.038)\end{array}$ \\
\hline$D_{\text {TGROUP }} x 2002$ & & & $\begin{array}{l}-.053 \star \\
(.023)\end{array}$ & & & $\begin{array}{l}-.151 \\
(.041)\end{array}$ \\
\hline$D_{\text {TGROUP }} x 2003$ & & & $\begin{array}{l}-.050 \star \\
(.020)\end{array}$ & & & $\begin{array}{l}-.1933^{\star} \\
(.042)\end{array}$ \\
\hline$D_{\text {TGROUP }} x 2004$ & & & $\begin{array}{l}-.052 \star \\
(.023)\end{array}$ & & & $\begin{array}{l}-.221 \star \\
(.046)\end{array}$ \\
\hline 1997 & $\begin{array}{l}-.002 \\
(.006)\end{array}$ & $\begin{array}{l}-.002 \\
(.006)\end{array}$ & $\begin{array}{l}.003 \\
(.017)\end{array}$ & $\begin{array}{l}-.006 \\
(.014)\end{array}$ & $\begin{array}{l}-.006 \\
(.015)\end{array}$ & $\begin{array}{l}.003 \\
(.019)\end{array}$ \\
\hline 1998 & $\begin{array}{l}-.002 \\
(.006)\end{array}$ & $\begin{array}{l}-.002 \\
(.006)\end{array}$ & $\begin{array}{l}.013 \\
(.017)\end{array}$ & $\begin{array}{c}.007 \\
(.013)\end{array}$ & $\begin{array}{l}.006 \\
(.014)\end{array}$ & $\begin{array}{l}.009 \\
(.018)\end{array}$ \\
\hline 1999 & $\begin{array}{l}-.002 \\
(.005)\end{array}$ & $\begin{array}{l}-.002 \\
(.005)\end{array}$ & $\begin{array}{c}.022 \\
(.016)\end{array}$ & $\begin{array}{c}.019 \\
(.013)\end{array}$ & $\begin{array}{l}.015 \\
(.014)\end{array}$ & $\begin{array}{l}.020 \\
(.018)\end{array}$ \\
\hline 2000 & $\begin{array}{l}-.000 \\
(.006)\end{array}$ & $\begin{array}{l}-.000 \\
(.006)\end{array}$ & $\begin{array}{c}.022 \\
(.017)\end{array}$ & $\begin{array}{c}.008 \\
(.015)\end{array}$ & $\begin{array}{l}.000 \\
(.015)\end{array}$ & $\begin{array}{l}.016 \\
(.019)\end{array}$ \\
\hline 2001 & $\begin{array}{c}.003 \\
(.006)\end{array}$ & $\begin{array}{l}.026{ }^{\star} \\
(.011)\end{array}$ & $\begin{array}{l}.022 \\
(.019)\end{array}$ & $\begin{array}{c}.026 \\
(.020)\end{array}$ & $\begin{array}{l}.040 \\
(.020)\end{array}$ & $\begin{array}{l}.040 \\
(.023)\end{array}$ \\
\hline 2002 & $\begin{array}{l}-.010 \\
(.007)\end{array}$ & $\begin{array}{l}.013 \\
(.011)\end{array}$ & $\begin{array}{l}.039 \\
(.021)\end{array}$ & $\begin{array}{c}.034 \\
(.020)\end{array}$ & $\begin{array}{l}.046 \text { * } \\
(.021)\end{array}$ & $\begin{array}{l}.051{ }^{\star} \\
(.024)\end{array}$ \\
\hline 2003 & $\begin{array}{l}-.024^{\star \star} \\
(.006)\end{array}$ & $\begin{array}{l}-.002 \\
(.011)\end{array}$ & $\begin{array}{l}.021 \\
(.018)\end{array}$ & $\begin{array}{c}.006 \\
(.017)\end{array}$ & $\begin{array}{l}.018 \\
(.018)\end{array}$ & $\begin{array}{l}.031 \\
(.021)\end{array}$ \\
\hline 2004 & $\begin{array}{l}-.019 \\
(.007)\end{array}$ & $\begin{array}{l}.003 \\
(.012)\end{array}$ & $\begin{array}{l}.028 \\
(.021)\end{array}$ & $\begin{array}{l}.018 \\
(.020)\end{array}$ & $\begin{array}{l}.029 \\
(.020)\end{array}$ & $\begin{array}{c}.048 \\
(.025)\end{array}$ \\
\hline $\ln ($ Turnover) & $\begin{array}{l}-.0144^{\star \star} \\
(.004)\end{array}$ & $\begin{array}{l}-.0144^{\star \star} \\
(.004)\end{array}$ & $\begin{array}{l}-.0144^{\star \star} \\
(.004)\end{array}$ & $\begin{array}{l}-.019 \\
(.007)\end{array}$ & $\begin{array}{l}-.017^{\star} \\
(.007)\end{array}$ & $\begin{array}{l}-.018 \text { * } \\
(.007)\end{array}$ \\
\hline Loss carry-forward & $\begin{array}{c}.009 \\
(.006) \\
\end{array}$ & $\begin{array}{c}.009 \\
(.005) \\
\end{array}$ & $\begin{array}{c}.009 \\
(.005) \\
\end{array}$ & $\begin{array}{l}-.011 \\
(.015) \\
\end{array}$ & $\begin{array}{l}-.013 \\
(.014) \\
\end{array}$ & $\begin{array}{l}-.014 \\
(.014) \\
\end{array}$ \\
\hline $\begin{array}{l}\text { Observations } \\
R^{2}\end{array}$ & $\begin{array}{c}18,787 \\
.024\end{array}$ & $\begin{array}{c}18,787 \\
.025\end{array}$ & $\begin{array}{c}18,787 \\
.025\end{array}$ & $\begin{array}{c}2,196 \\
.057\end{array}$ & $\begin{array}{c}2,196 \\
.077\end{array}$ & $\begin{array}{c}2,196 \\
.090\end{array}$ \\
\hline
\end{tabular}

Dependent variable is the share of inter-company loans borrowed from the foreign parent company. Specifications (1) -(3) are based on a sample of ordinary corporations and partnerships. Specifications (4) - (6) are based on a sample, which consists of holding corporations and partnerships. Robust and clustered (country/year clusters) standard errors are in parentheses. A star denotes significance at $5 \%$ and two stars at the $1 \%$ level. All estimates include a full set of 5,105/738 firm, 56 industry, and year fixed effects. 
In table 4 we split the sample according to different treatment groups. As already mentioned, we have two treatment groups in the 2001 reform case, i.e. holdings and ordinary incorporated companies. The results are generally comparable, apart from the fact that the number of observations is reduced. ${ }^{6}$ The specifications (1)-(3) consider treated ordinary corporations as well as partnerships as the control group. Whereas specifications (4)-(6) investigate the tax effects on intra-firm debt of holding corporations; partnerships constitute again the control group. One major insight from table 4 is that holdings are adopting their capital structure much faster than ordinary incorporated companies. Possibly, the restructuring process is for some reason easier and therefore faster in the case of holding corporations, which serve as special tax planning entities. Moreover, the threshold level was reduced more severely for holding corporations.

The magnitude of the treatment effects can be interpreted as follows. For holding corporations, the thin-capitalization reform 2001 induced a decline in the share of internal debt borrowed from the foreign parent company of about 10 percentage points. This equals a reduction of around one-third, considering a pre-reform mean of 31.7 per cent intra-firm debt to total capital.

Finally, we focus on the effect of the German thin-capitalization reform in 2004. In this reform only holding corporations were treated. The control group consists of all other legal forms. The results in table 5 show again that some companies restructure, basically those which were affected by the more stricter rule, and reduce their internal debt share, i.e. the mean debt share is going down for the treated group. Specifications (1) and (2) are based on observations from 1996 - 2004. However, regressions in columns (3) and (4) are only based on observations of 2001 until 2004 in order to avoid the effect of the first thin-capitalization reform in 2001.

The magnitude of the 2004 reform effect is much less, compared to the 2001 reform. For

\footnotetext{
${ }^{6}$ Note, however, that the number of companies in the three different groups are relatively constant for the 9 years in the sample.
} 
Table 5: Inter Company Loans - Thin-Capitalization Reform in 2004

\begin{tabular}{|c|c|c|c|c|}
\hline & $\overline{(1)}$ & $\overline{(2)}$ & $\overline{(3)}$ & $\overline{(4)}$ \\
\hline$S T R_{G}-S T R_{F}$ & $\begin{array}{l}.192{ }^{\star} \\
(.088)\end{array}$ & $\begin{array}{l}.193 \text { * } \\
(.088)\end{array}$ & $\begin{array}{l}.406 \text { * } \\
(.201)\end{array}$ & $\begin{array}{l}.410 \text { * } \\
(.200)\end{array}$ \\
\hline$D_{T G R O U P}$ & & $\begin{array}{l}.050 \text { * } \\
(.020)\end{array}$ & & $\begin{array}{l}.026 \\
(.024)\end{array}$ \\
\hline$D_{\text {TGROUP }} x D_{2004}$ & & $\begin{array}{l}-.068 \star \\
(.021)\end{array}$ & & $\begin{array}{l}-.042 \star \\
(.019)\end{array}$ \\
\hline 1997 & $\begin{array}{l}-.003 \\
(.005)\end{array}$ & $\begin{array}{l}-.003 \\
(.005)\end{array}$ & & \\
\hline 1998 & $\begin{array}{l}-.002 \\
(.006)\end{array}$ & $\begin{array}{l}-.002 \\
(.006)\end{array}$ & & \\
\hline 1999 & $\begin{array}{l}-.001 \\
(.005)\end{array}$ & $\begin{array}{l}-.001 \\
(.005)\end{array}$ & & \\
\hline 2000 & $\begin{array}{l}-.000 \\
(.006)\end{array}$ & $\begin{array}{l}-.000 \\
(.006)\end{array}$ & & \\
\hline 2001 & $\begin{array}{c}.002 \\
(.005)\end{array}$ & $\begin{array}{c}.002 \\
(.006)\end{array}$ & & \\
\hline 2002 & $\begin{array}{l}-.010 \\
(.007)\end{array}$ & $\begin{array}{l}-.011^{\star \star} \\
(.007)\end{array}$ & $\begin{array}{l}-.014^{\star \star} \\
(.004)\end{array}$ & $\begin{array}{l}-.014 \\
(.004)\end{array}$ \\
\hline 2003 & $\begin{array}{l}-.024 \\
(.006)\end{array}$ & $\begin{array}{l}-.024 \\
(.006)\end{array}$ & $\begin{array}{l}-.034 \\
(.005)\end{array}$ & $\begin{array}{l}-.035 \\
(.005)\end{array}$ \\
\hline 2004 & $\begin{array}{l}-.022^{\star \star} \\
(.007)\end{array}$ & $\begin{array}{l}-.020^{\star \star} \\
(.007)\end{array}$ & $\begin{array}{l}-.029 \\
(.005)\end{array}$ & $\begin{array}{l}-.028 \\
(.005)\end{array}$ \\
\hline $\ln$ (Turnover) & $\begin{array}{l}-.015^{\star \star} \\
(.004)\end{array}$ & $\begin{array}{l}-.015^{\star \star} \\
(.004)\end{array}$ & $\begin{array}{l}-.009 \\
(.007)\end{array}$ & $\begin{array}{l}-.009 \\
(.007)\end{array}$ \\
\hline Loss carry-forward & $\begin{array}{l}.009 \\
(.005)\end{array}$ & $\begin{array}{l}.009 \\
(.005)\end{array}$ & $\begin{array}{l}.026 \\
(.010)\end{array}$ & $\begin{array}{l}.026 \text { * } \\
(.010)\end{array}$ \\
\hline $\begin{array}{l}\text { Observations } \\
R^{2}\end{array}$ & $\begin{array}{c}19,379 \\
.026\end{array}$ & $\begin{array}{c}19,379 \\
.027\end{array}$ & $\begin{array}{c}7,980 \\
.045\end{array}$ & $\begin{array}{l}7,980 \\
.046\end{array}$ \\
\hline
\end{tabular}

Dependent variable is the share of inter-company loans borrowed from the foreign parent company. Specifications (1) - (2) are based on the whole sample, whereas (3) and (4) are based on a sample, where only observations from 2001 until 2004 are considered. Robust and clustered (country/year clusters) standard errors are in parentheses. A star denotes significance at $5 \%$ and two stars at the $1 \%$ level. All estimates include a full set of 5,257 or 3,196 firm, and 56 industry fixed effects. 
holdings the share of intra-firm debt borrowed from the foreign parent company is reduced by around 4.2 percentage points. This equals a reduction of about one sixth, given the pre-reform level of 26 per cent intra-firm debt to total capital.

\section{Conclusion}

We find that taxes, especially the tax rate difference between Germany and foreign countries, play an important role in determining the share of internal lending to German affiliates. This confirms earlier results provided by other studies. The important insight of our empirical analysis is that German thin-capitalization rules are effectively imposed. A reduction of the allowed debt-to-equity ratios, enforced by reforms in 2001 and 2004, respectively, induced significantly smaller shares of inter-company loans of incorporated companies.

Finally, let us focus on revenue effects. Although we cannot estimate how much revenue Germany would lose if there were not any restrictions, i.e. if there was not a thincapitalization rule, rough estimations of the reform effects should be possible. First of all, we take specifications (3) and (6) from table 4. In 2002 the treatment of the 2001 reform is associated with .053, for ordinary corporations, and .151, for holding corporations, lower internal debt to capital ratios. Evaluated at the respective mean values, Germany was able to keep on average approximately $€ 71,700$ per ordinary corporations and $€ 1,807,000$ per holding corporation additional tax revenue through the tightening of the thin-capitalization rule. $^{7}$ Considering the number of corporations treated, an amount of approximately $€ 260$ million additional tax revenue is estimated. Secondly, using specification (4) of table 5, we estimate additional tax revenue up to approx. $€ 30$ million for the 2004 reform. Probably, the total amounts might be higher due to the treatment of indirect held foreign affiliates or

\footnotetext{
${ }^{7}$ We assume as price for the internal credit the German lending rate of $9.7 \%$ in 2002, and the 2002 statutory tax rate, $32.88 \%$.
} 
of other debt types. Moreover, the internal lending rate is not necessarily equivalent to the local lending rate; most probably it is set a bit beyond that level. Recognize also that all estimated magnitudes are only rough estimates, where we cannot take into account that multinationals - in case of restrictions on their free choice of capital structure - are able to shift profits through other channels, e.g. by transfer price setting.

Obviously, Germany is aware that multinationals exploit tax planning opportunities. Therefore, the state restricts these activities effectively. However, if corporations are able to shift profits, adverse investment effects of profit shifting restrictions will be likely (see Buettner et al., 2006b). Hence, this trade-off should also be considered in future policy reforms.

\section{Data Sources and Definitions}

Firm-level data are taken from the micro-level dataset of the Bundesbank, see Lipponer (2006) for an overview. The intra-firm debt share from the foreign parent company is determined by the level of balance-sheet liabilities in the respective category divided by total capital consisting of registered capital, capital reserves and profit reserves, as well as internal and external debt.

Corporate taxation data are taken from the IBFD, and from tax surveys provided by the tax advisory companies Ernst\&Young, PwC and KPMG.

\section{References}

Buettner, T., M. Overesch, U. Schreiber, and G. Wamser (2006a), Taxation and the choice of capital structure - Evidence from a panel of German multinationals, ZEW Discussion Paper 06-067, Mannheim.

Buettner, T., M. Overesch, U. Schreiber, and G. Wamser (2006b), The impact of thin- 
capitalization rules on multinationals' financing and investment decisions, CESifo Working Paper 1817, Munich.

Desai, M.A., C.F. Foley, and J.R. Hines (2004), A multinational perspective on capital structure choice and internal capital markets, The Journal of Finance 59, 2451-2487.

European Communities (2005), Structures of the taxation systems in the European Union, Data 1995-2003, Luxembourg.

Fuest, C. and T. Hemmelgarn (2005), Corporate tax policy, foreign firm ownership and thin capitalization, Regional Science and Urban Economics 35, 508-526.

Huizinga, H., L. Laeven, and G. Nicodème (2006), Capital structure and international debt shifting in Europe, Paper presented at the European tax policy forum conference 'The impact of corporation taxes across borders', London.

Jensen, M. and W.H. Meckling (1976), Theory of the firm: managerial behavior, agency costs and ownership structure, Journal of Financial Economics 42, 159-185.

Jensen, M. (1986), Agency costs of free cash flow, corporate finance and takeovers, American Economic Review 76, 323-329.

Jog, V. and J. Tang (2001), Tax reforms, debt shifting and tax revenues: Multinational corporations in Canada, International Tax and Public Finance 8, 5-26.

Lipponer, A. (2006), Microdatabase Direct Investment-MiDi. A brief guide, Bundesbank Working Paper, Frankfurt.

MacKie-Mason, J. (1990), Do taxes affect corporate financing decisions? The Journal of Finance 45, 1471-1493.

Meyer, B.D. (1995), Natural and quasi-experiments in economics, Journal of Business and Economic Statistics 13, 151 - 161. 
Mintz, J. and M. Smart (2004), Income shifting, investment, and tax competition: theory and evidence from provincial taxation in Canada, Journal of Public Economics 88, $1149-1168$.

Modigliani, F. and M. Miller (1958), The cost of capital, corporation finance, and the theory of investment, American Economic Review 48, 261-297.

Modigliani, F. and M. Miller (1963), Corporate income taxes and the cost of capital: a correction, American Economic Review 53, 443-453.

Myers, S. (1977): Determinants of corporate borrowing, Journal of Financial Economics, $5,147-175$.

Panteghini, P. M. (2006), The capital structure of multinational companies under tax competition, CESifo Working Paper 1721, Munich.

Ramb, F. and A.J. Weichenrieder (2005), Taxes and the financial structure of German inward FDI, Review of World Economics (Weltwirtschaftliches Archiv) 141, 670-692. 